\title{
The General School System as a Universal or a Particular Institution and Its Role in the Formation of Social Capital
}

\author{
Tomas Englund \\ Örebro University
}

\begin{abstract}
In recent decades, the concept of social capital has had an enormous impact on the social scientific debate. Despite its vagueness, the concept expresses a distinction that is of significance for the maintenance and depth of democracy. At the same time, the overarching thesis put forward concerning the fundamental role of associations and social networks in the creation of social capital is not convincing.

In this article the role of universal institutions, and primarily of one such institution, the general school system, in creating social capital is emphasized. The discussion gradually homes in on Swedish society and the changes it has undergone in recent decades. The term "universal institution" with reference to the Swedish compulsory school system is examined.
\end{abstract}

Keywords: social capital, universalism, schools as universal institutions, deliberation

\section{Education and Social Capital}

In the late modern Western societies of today, Sweden included, democracy is considered by some to be under threat, in that social capital, which is seen as one of its central preconditions, is in danger of being undermined. ${ }^{1}$ It was the well-known (educational) sociologist James Coleman who late in his career, and drawing on the work of many predecessors, succeeded in introducing the concept of social capital on a broad front, and also in relating it to education (Coleman, 1988). But it is the works of Robert Putnam and the meaning of the concept that he develops that have had a major impact and that form our starting point here. Putnam (2000) defines social capital as follows:

Whereas physical capital refers to physical objects and human capital refers to properties of individuals, social capital refers to connections among individuals - social networks and the norms of reciprocity and trustworthiness that arise from them. In that sense social capital is closely related to what some have called "civic virtue". The difference is that "social capital" calls attention to the fact that civic virtue is most powerful when embedded in a dense network of reciprocal social relations. A

Tomas Englund, Department of Education, Örebro University, Sweden.

Correspondence concerning this article should be addressed to Tomas Englund, Department of Education, Örebro University, SE 70182 Örebro, Sweden. E-mail: tomas.englund@oru.se

${ }^{1}$ To what extent democracy is in fact under threat today can of course be discussed. The current critique says that support for democracy from people in general is gradually being undermined, a trend that is reflected in lower turnouts at general elections, difficulties recruiting people for political and other positions of trust, and a growing egoism and possessive individualism that are questioning our collective public institutions. 
society of many virtuous but isolated individuals is not necessarily rich in social capital (p. 19).

However, different views exist about the mechanisms giving rise to the social capital, which, by creating trust between people, constitutes one of the central preconditions of democracy. Dietlind Stolle (2003), for example, claims in a recent critical overview, partly directed against Putnam's thesis, that:

the importance of voluntary associations as the center and main measure of social capital has been called into question. Second and moreover, we have also suggested that the assumption of most social capital theorists as to the efficacy of voluntary associations in producing generalized norms and values such as trust should be taken with caution at best. There is no strong empirical evidence to confirm the microrelationship between membership and trust. (p. 35)

In a similar critique of Putnam, who stresses the role of associations (but without distinguishing their different qualities ${ }^{2}$ ), Rothstein (2005) argues that "universal" institutions, rather, are the decisive factor in creating social capital and trust between people:

The truth of the situation may be precisely the opposite of what Robert Putnam, and many in his wake, have proposed. The causal connection may not go from the sociological level (individuals-networks) to the political (the state and its institutions), but rather the reverse. It may be that a particular type of state institutions produces individuals and organizations with high (or low) social capital. Now that the nearly organic view of the emergence of social capital triggered by Putnam's work is proving incorrect, there is reason to think along different lines. Maybe it is a particular type of political institution that produces social capital, rather than social capital being produced by a particular type of political institution. (p. 104)

Trust and social intelligence, Rothstein argues, develop through extensive interaction with others, and mainly with others who are not of the same category as oneself. Societies have to create arenas for social encounters where this interaction can come about. Rothstein also proposes that the general school system potentially offers such an arena. ${ }^{3} \mathrm{It}$

\footnotetext{
${ }^{2}$ A point to be noted is that Putnam (and many after him) makes no distinction as regards the type of association that is seen as a precondition for the development of social capital. Here, Dewey (1916/1985) may serve as a reminder: "Now in any social group whatever, even in a gang of thieves, we find some interest held in common, and we find a certain amount of interaction and cooperative intercourse with other groups. From these two traits we derive our standard. How numerous and varied are the interests which are consciously shared? How full and free is the interplay with other forms of associations?" (p. 89)

${ }^{3}$ Rothstein's critique, a follow-up of his thesis that "just institutions matter" (Rothstein, 1998), is part of a larger battery of critique against Putnam's theses, questioning the latter's bottom-up perspective, which stresses the role of free association in the development of social capital. Rothstein and many others point, rather, to the development of social capital as a consequence of political institutions (Berman, 1997; Foley \& Edwards, 1998; Levi, 1998; Tarrow, 1996; cf. Stolle, 2003). However, what should be noted here is the fact that Rothstein specifically identifies the educational system as a universal institution. This view of the potential of the educational system-to create a
} 
seems reasonable, Rothstein (2005) suggests, with reference to Toshio Yamagishi (2001), that "such societies should have educational systems, from pre-school to university level, that do not segregate on the basis of, for example, ethnicity and social class" (p. 99). The educational system is also regarded by Rothstein, referring to Russell Hardin (2002), as a typical example of a universal institution. ${ }^{4}$ However, universal institutions are not just difficult to establish, they also tend to be weak and are thus often at risk of being dissolved. There are always different particular interests that tend to challenge universal institutions on the grounds that their own group is being singled out for special treatment or put at a disadvantage by existing institutions of this kind.

\section{The Swedish General Education System-A Universal or a Particular Institution? Two Problem Areas}

The first area I wish to focus on here is, thus, the vulnerability of universal institutions, and more specifically of the general education system as a universal institution. To shed light on this area I will in the following begin by analysing the preconditions for the Swedish general system of education as a universal institution from a historical point of view and by trying to show how Sweden's compulsory comprehensive school system was created as a universal institution.

The second area I will try to analyse is the current state of the debate about how the general education system (as a universal institution or otherwise) should operate today and in the future, and what preconditions the different views on this subject imply in terms of creating social trust, social intelligence, and social capital. Here I will also shed light on the importance of the emergence of parents' rights in the arena of schooling and the potential relationship between deliberation (deliberative communication in schools and deliberative democracy) and social capital. Linked to this issue, I will in addition ask questions about the central core of schooling, and the meaning of teacher professionalism (cf. Englund, 1996a).

\section{The Vulnerability of the Swedish School System as a Universal Institution}

The development of Swedish society in recent decades, which has seen what can be described as an ongoing transformation of democracy in the country (Englund, 1994a, 1994b, 2005), has been such that the educational system - as a universal institution - has been called into question. That is to say, it has been questioned not as an institution per se, but more precisely as an institution of a universal character, in the sense of a meeting place common to all, which does not segregate and which is more or less equal for all and oriented towards equality. The general educational system common to all has thus been

public good and promote trust between citizens in society-has been stressed by many educational researchers and is, or rather has been, as I will make clear later on in this article-one characteristic of the Swedish school system.

${ }^{4}$ The term universal can be discussed, and it should be noted that according to Rothstein, the universalism, or rather degree of universalism, of institutions is a question of how impartial, objective and equal in their treatment of people those institutions are. Variations in the supply of social capital in a society are mainly, Rothstein argues, a result of the degree of universalism of its institutions. It is with this basic starting point that the universalism of the general school system is analysed in the following. 
challenged by particular interests that, to a certain extent in the name of democracy, but primarily in the name of the right to choose, have introduced school choice and demanded and established independent schools in line with needs related to specific parent groups and their children. In concrete terms, this means that the general, universal system of education has been undermined with regard to its universalism. Alternative, particularistically-based independent schools and other particular elements, such as school choice and specialist or theme schools, have become established - a particularist school system that is growing year by year.

Questions that can be asked regarding the longer-term implications of this trend are whether it will remain possible to regard the general education system as a universal institution that is desirable from the standpoint of democracy; and whether a growing particularist independent school system, founded on ethnicity, language, religion, etc., should be seen as a threat to universalism, or whether such a system and increasing freedom of school choice should be seen as a deepening of democracy. In this area there are a range of well-known and established points of view, but my focus in the following will be on examining the general education system specifically as a universal institution, in the light of the role of such an institution in producing social capital.

The more precise questions that can be posed are therefore: What are the historical premises for the establishment of a general or universal education system, and what are the current premises for its possible preservation? What significance can in fact be ascribed to the historical premises and motives for the establishment of a general education system (if it can be said to have been established as a universal institution at all), ${ }^{5}$ and what possible arguments exist for such a system today?

What I would regard as the most central question is the tension between universalism and particularism in relation to the current situation, and I am especially interested in the arguments for and against the general education system as a universal or particular institution. It is, to most of us, quite clear that the educational system as a universal institution, common to all and democratically governed, has been challenged in most Western countries (including the USA, Britain, and Sweden), and questioned from different points of view. Many of these can be seen as particularistic (involving, for example, calls for the establishment of private schools, opportunities for school choice, etc.), with the rights of parents as a starting point. In certain cases the existing system of democratic control of the general education system and the equal treatment of pupils have thus been questioned, but at the same time there are those who have argued the case for parents' rights as a more democratic principle.

Against this background, further questions that can be asked are: What tasks the educational system can and ought to have in the context of the current transformation of democracy? What kind of educational system, universal or particular, can offer the best response to this transformation and what consequences different models will have? Here I would refer back to what was said by way of introduction about universal institutions and

\footnotetext{
${ }^{5} \mathrm{~A}$ rather obvious objection to seeing historically established national education systems as universal is of course the very fact that they have a national basis, that they were often created as propaganda centres for the inculcation of national values, and so on. This historical base is not necessarily eternal, however, even if it seems to represent a very strong tradition (cf. Englund [1986] where, with regard to the Swedish educational system I differentiate between a patriarchal, a scientific-rational, and a democratic conception).
} 
the creation of social capital. Can and should the educational system continue to operate as a universal institution and hence as a producer of social capital? Is it possible for an educational system based on particular interests to produce social capital? How are teachers as professionals to strike a balance between the knowledge- and democracyrelated tasks of schools?

\section{The Swedish compulsory comprehensive school as a universal project?}

Sweden's compulsory elementary schools (folkskolan) were historically part of a segregated system of parallel forms of education in which the grammar schools (läroverk) were intended for a social elite and in which it only gradually became possible to progress from elementary to grammar school. The period from the breakthrough of political democracy in Sweden in 1918-1921, which coincided with the introduction of a new elementary school curriculum, a compulsory continuation school, etc., and the period just after the Second World War, characterized in particular by the School Commission's proposals for a democratically oriented school system (SOU, 1948, p. 27), may be seen as the two main phases in the building of an educational system as a universal institution: the compulsory, nine-year comprehensive school system.

The school as a universal institution was given a special character by the School Commission's report, namely an explicit relationship to democracy, which was articulated in the goals set for the future school system in the government bill that followed (Prop. 1950 , p. 70). It was assumed that individual members of society could be given responsibility for democracy by being educated at school as democratic individuals. The rationale was that schools would educate free people who would be ready to shape society by democratic means. This forward-looking democratic goal was somewhat weakened in the 1950s in the run-up to the educational reform of 1962 that introduced the nine-year compulsory comprehensive school, but was basically maintained after that, growing stronger again during the 1970 s. $^{6}$

Around 1989/1990, however, the basic conditions for schooling for democracy were fundamentally altered when doors were opened for the establishment of publicly funded independent schools, for school choice and specialist schools, for changes in school governance, etc. $^{7}$

Can Sweden's compulsory comprehensive school system be seen as a universal institution from the vantage point of contemporary history? Well, it might only be from 1962 to 1989/1990, a period of less than 30 years in all, that a more or less pronounced universalism characterized the country's education system. During that period, the comprehensive school was a nine-year, mixed-ability school attended by all, and with a strong emphasis on promoting equality (cf. Englund, 1989b).

\footnotetext{
${ }^{6}$ In an earlier work (Englund, 1986) I have analysed this period as one in which an attempt was made to balance a democratic and a scientific rational conception of education. Translated into the terms of a later philosophy of science debate, it might be said that the democratic conception of education was, to use Rorty's (2000) words, a matter of "abandoning the logocentric idea that knowledge is the distinctively human capacity" in favour of "the idea that democratic citizenship is better suited for that role." (p.3)

${ }^{7}$ Cf. Englund (1994a, 1994b); Englund (1996b); Wahlström (2002). For a debate illustrating the arguments advanced for the change at the time, see Rothstein (1988) and Englund (1989a).
} 
A key manifestation of the comprehensive school as a universal institution is the fact that its teachers gradually assumed a specific form of professionalism (cf. Englund, 1996a), namely one that involved serving as mediators between the state (and its democratically reached decisions on the activities of schools) and the students, and that had certain clear implications. The professional teacher was the central mediator of knowledge and also had the formal task of assessing each student's achievements, and in that process he or she became an integral part of the differentiating function of the educational system. At the same time, the encounter with the professional teacher represented, for each individual student, an encounter with society and a disengagement from his or her family. This also meant that the comprehensive school had the task of bringing about an institutionalized socialization that implied an encounter with societal values and norms at a public level, compared with the private level of the family. ${ }^{8}$

The Swedish comprehensive school of the 1960s, 1970s and 1980s, then, may possibly be described as a universal institution, but during the same period it was also criticized and challenged by different particular interests. During the 1960 s it was criticized by religious groups who felt that the school system's role of inculcating Christianity was being neglected as a result of the requirement, inscribed in the 1962 curriculum, that education should be religiously neutral and that teachers should be objective. During the 1970s the comprehensive school system was criticized by left-wing groups who saw it as an instrument of social selection and indoctrination. During the 1980s the criticism came from a private middle class who regarded the system as imposing too uniform a socialization, and leaving no room for individual differences and the wish of parents to shape their children's education. However, it was only the authors of this last wave of criticism who called for "schools of their own", and it was also this last wave that paved the way for the disintegration of the general school system as a universal institution with the reforms introduced around 1990.

What happened during the 1980s (a subject that requires an exhaustive historical analysis of its own, which cannot be attempted here and now) was that the Swedish comprehensive school system was called into question. Or, to put it another way, the legal basis for it which had been dominant until then, the idea of school education as a social citizenship right for all children, was questioned by a civil rights-based view, which looked at the right to schooling as a family or parental right. ${ }^{9}$

\footnotetext{
${ }^{8}$ The more precise meaning of the relationship that emerged between comprehensive school teachers and students is of course difficult to characterize in unambiguous terms, and the relationship may be seen as a multifaceted one. However, in my view the perspectives outlined by Parsons (1959) in "The school class as a social system" and Durkheim's (1957) thoughts on teachers as professionals, further developed by Parsons, may deepen our understanding of the comprehensive school as a universal institution. A historically problematic point is of course the more exact meaning of "societal values and norms", which can be said to have shifted from a more definite and determined set of values and norms (a common frame of reference), at the same time as teachers were supposed to be objective, to what could later be described as a more pluralistic and tolerant attitude. However, the latter outlook, which saw the comprehensive school as a manifestation of pluralism and openness, does not seem to have made much of an impression on the public debate, which tended to depict the school system as pressing all its students into the same mould.

${ }^{9}$ The vocabulary of rights referred to here is that of Marshall (1949), with his classic classification in terms of civil, political and social rights (cf. Englund, 1989b, 1994a and Englund, 1996b).
} 
Independent schools were created on a number of different foundations. Initially (in the 1980s), the debate centred on the establishment of schools pursuing alternative educational approaches (Steiner Waldorf, Montessori, etc.), but the crucial phase in the emergence of independent schools came during the second half of the 1980s when, within a short space of time, (fundamentalist) religious schools found acceptance with the Swedish government, at the same time as a couple of inquiries and subsequent government bills created totally new possibilities for starting independent schools.

In addition to alternative educational methods and religion as a basis for setting up such schools, there were other rationales. As with the grounds just mentioned, one important starting point was the view, held by many groups, that the comprehensive school system was not sufficiently "effective" and/or that it treated their children unfairly. Various groups argued, for example, that talented children of various kinds were unable to develop optimally, that children with a first language other than Swedish were put at a disadvantage, and that the same applied to children with a non-Swedish ethnic background. In most cases the establishment of independent schools meant that schools were set up with aims and emphases different from those the comprehensive school system was perceived to represent. ${ }^{10}$

One possible reason for the dissolution of the comprehensive school as a universal institution, however, was that very few people came to its defence and tried to articulate the value of a universal system of education. In line with Hardin (2002), the risk of particular interests challenging the school as a universal institution was confirmed by the argument that particular groups' own children were being treated unfairly. The social forces, liberal and social democratic, which historically had been key players in the establishment of the comprehensive school as a universal institution, were startlingly reserved as its defenders. Basically, they simply adjusted to a national and international process that quite rapidly, in the climate of opinion that developed, assumed the character of a necessary development. ${ }^{11}$ What is noticeable at this time is that - with the governmental official report Study of Power and Democracy (1985-1990: SOU, 1990, p. 42) as a catalyst, and with a media structure in which the non-socialist press was clearly dominant and the daily Dagens Nyheter holding a privileged position in terms of defining the issues of the day - there had developed a climate of debate in which universal institutions like the general education system (the comprehensive school) and public service television and radio were pilloried. Instead, the opinion-forming instances mentioned, and others, proclaimed the need to develop "smallscale democracy," the necessity of individual choice, and the right of parents, for example, to start independent schools. ${ }^{12}$

\footnotetext{
${ }^{10}$ One clear exception may be mentioned here, however, in which there was no criticism of the aims and emphases of the comprehensive school system: this was in cases where there were insufficient pupils for a small village school to survive. Of course, another question that arises here is that of the steering force of the national curriculum. However, I will not go into detail on that issue here (cf. Englund, 1996b, ch. 8).

${ }^{11}$ That the school as a universal institution could be a central factor in building what has come to be called social capital was not a dominant argument at this time, even if the idea did occasionally figure in the debate.

${ }^{12}$ By opinion-forming instances I mean the Study on Power and Democracy and Dagens Nyheter (cf. Englund, 1996b). The situation can be said to confirm Hardin's analysis that universal institutions are often weak, and that there is a risk of their dissolving if there is no social force ready to defend them (cf. Hardin, 2002 and Rothstein, 2005).
} 


\section{ENGLUND}

In the last couple of decades, then, the Swedish comprehensive school as a universal institution has been both questioned and partially transformed, in that a system of independent schools has been established in parallel with the general education system. At the same time, there have been profound changes within the general system of education. The particularist demands and challenges have had different bases and assumed different shapes, but the primary manifestation of particularism must be said to be that the organization, content, and form of schools have become more closely tied to the particular wishes of individual parents and families. The starting point for this development has been a criticism of the general education system for having (allegedly) failed in several respects, a criticism that has gradually given rise to particular alternatives (independent schools) to the earlier universal arrangements (the general education system/the comprehensive school). Especially in the larger towns and cities, but eventually on a broader front as well, the independent school system has grown ever stronger, and over the last decade marketoriented chains of such schools, that is companies offering independent education, have been established.

Briefly, one major consequence of this expansion of independent schools is that a traditional view of knowledge has become more prominent. This is a general trend, the primary exceptions here being schools based on alternative educational methods, which were the first to challenge the general education system. The democratizing role of the school system, its role as an arena for encounters between interacting citizens from different social groups and cultures, has gradually been neglected. Its societal role can now possibly, given the greater emphasis being placed on traditional education, be seen more in terms of individual and societal efficiency with respect to knowledge reproduction. The expansion of independent schools, together with the restructuring of the general education system, has thus also played a part in shifting the aims of school education away from the promotion of democracy towards the reproduction of knowledge, and for some years now the focus has been on recurrent evaluations of students' knowledge.

An insistence on evaluation forms an integral part of the international restructuring of school education, with internationally organized assessments such as TIMMS and PISA as powerful influences. Evaluation has also become an increasingly prominent national concern, as knowledge requirements and pass/failure rates in Swedish, English, and Mathematics have become the hard currency of educational debate.

\section{The Current Status of Arguments Pro et Contra Schooling as a Universal Institution}

In the system shift that has occurred in educational policy, the school as a universal institution has been described by many as undemocratic in its uniformity, and the emerging particularist demands - for school choice, establishment of independent schools, etc. - have been seen by their advocates as strengthening democracy (in line with the Study of Power and Democracy's call for a more individually-based view of democracy, and as a reflection of the goal of strengthening small-scale democracy). I will not analyse in more depth here the field of force between what, exemplified in the arena of schooling, have been referred to as large-scale or "big democracy" (deciding on a common school system for all students and on its content and form within the framework of a national parliamentary democracy) and small-scale democracy (giving parents a greater local say 
and providing opportunities for school choice etc.). ${ }^{13}$ I will focus instead on the terminology of universalism and particularism.

What is clear in relation to the questions addressed in this study is that the value of the school as a universal institution has hardly been articulated at all in the public debate of recent decades (cf. Englund, 1996a). Diversity and different needs have for a long time been given higher priority than similarity and equality, and it is the individual rather than the citizen who is now in focus. ${ }^{14}$

Here, equivalence (Swedish likvärdighet) can be said to have established itself as a mediating concept, via a streamlined, standardized, and narrowed concept of knowledge linked to the achievements of the individual, and with room for completely different forms of school (local authority-run or independent). At the same time, we can also see moves towards a concept of equivalence that operates at a more ambitious, universal level, encompassing other dimensions as well. ${ }^{15}$ Expressions of this latter trend can be found within the debate on constituting values of the late 1990s and early 2000s, some participants in which have regarded the development of a common value base as a necessity.

But to claim, in the spirit of the latest national curriculum (Ministry of Education, 1994), that this common value base is founded in "Christian tradition and Western humanism" can only be seen, in a multicultural society, as representing a communitarian challenge. Christian tradition can hardly be seen as universal, but is inescapably a special interest, an expression of particularism.

To see a common value base as a possible procedural means of maintaining universalism in order to create a common political culture, i.e. a culture with common rules as a precondition for communication between citizens, is another, and possibly a more reasonable, approach. ${ }^{16}$ One proposal along these lines is the present author's call

${ }^{13}$ As I have mentioned, the Study of Power and Democracy (SOU, 1990, p. 44) was an important catalyst in this process, and it was that study that brought into focus the field of force between largeand small-scale democracy.

${ }^{14}$ There has been a clear shift from seeing the central role of schooling as being to contribute to a citizenship education that gives everyone a common frame of reference, and to promote interacting citizens ready to participate in political life, to a view of the school system as a differentiated institution meeting the individual needs of parents and children without stressing the societal and citizenship dimension. With reference to the history of ideas and de Tocqueville, it could be said that the individual is the worst enemy of the citizen: "as de Tocqueville long ago suspected, setting people free makes them indifferent....The individual tends to be lukewarm, sceptical, or wary of the 'common good', of the 'good society' or 'just society'. What is the sense of common interests unless they let each individual satisfy her or his own?" (Baumann, 2001, pp. 48-49).

${ }^{15}$ Concerning interpretations of the concept of equivalence, see Englund, 2005 and the studies carried out as part of the research project What about equivalence? (Englund \& Quennerstedt, 2008). Within this project, financed by the Swedish Research Council, analyses have been made of different municipalities' interpretations of equivalence (Quennerstedt, 2006), the relationship between knowledge and equivalence (Wahlström, 2008), and the relationship between free choice and equivalence (Olson, 2008), and developments in Sweden have also been compared with those at the international, and especially the European, level (Moreno \& Francia, 2004). See also Englund \& Quennerstedt, 2008b.

${ }^{16}$ Obviously, though, there will be several issues to ponder here, such as the scope of the community, the level of the rules of the political culture, and so on. 
for deliberative communication within the general education system. Deliberative communication implies communication in which:

(1) different views are confronted with one another and arguments for these different views are given time and space and are articulated and presented (cf. Gutmann \& Thompson, 1996; Habermas, 1987, 1996);

(2) there is tolerance and respect for the concrete other, and participants learn to listen to the other person's argument (Benhabib, 1992; Habermas, 1987, 1996);

(3) elements of collective will formation are present, that is an endeavour to reach consensus or at least temporary agreements and/or to draw attention to differences (Habermas, 1987, 1996; Gutmann \& Thompson, 1996);

(4) authorities/traditional views (represented, for example, by parents and tradition) can be questioned and there are opportunities to challenge one's own tradition (Gutmann, 1987; Nussbaum, 1997);

(5) there is scope for students to communicate and deliberate without teacher control, that is for argumentative discussions between students with the aim of solving problems or shedding light on them from different points of view (Hoel, 2001). ${ }^{17}$

It may be noted, however, that in the present situation, with independent schools widely established, such a starting point may give rise to differing interpretations, for example concerning the potential contradictions between the rights of parents and of children.

\section{The Character of Parents' Rights}

The most problematic aspect in the field of force between universalism and particularism is, as I see it, that the right of parents inscribed in article 26 of the Universal Declaration of Human Rights - which gives parents a prior right to choose the kind of education to be given to their children - is a particular and not a universal right. It thus creates fundamental conditions for a particularist system of schools based specifically on the interests of parents. ${ }^{18}$ In my view, there is an important paradox here in relation to the view of the creation of social capital that was analysed earlier. Accordingly, the Declaration, which no doubt is understood by many as universal in its aims, forms - at least as far as parents' rights in the area of education are concerned-a central foundation for particularism.

It is also particularist arguments, propagated by the anti-socialist media, that have enjoyed a clear precedence in Sweden in recent decades. Nor has there been any articulated defence of a universal system of education from the social democrats, the social force that played a dominant role in establishing the general education system, and that has traditionally defended it as a universal institution. On the contrary, that force has gradually accepted, and even supported, the tendency towards particularism.

One could say that particularism has been strengthened by an increasing emphasis on the recognition of and need to accept difference, a trend that has grown stronger with

\footnotetext{
${ }^{17}$ Englund (2000, 2001, 2006).

${ }^{18}$ In the earliest phase in the establishment of independent schools in Sweden, in the early 1990s, the Universal Declaration of Human Rights was frequently invoked.
} 
globalization, increasing migration, etc. The current emergence of identity politics, in both its progressive and its reactionary forms, has, according to more discerning analysts, often tended to detach the fight for recognition from the historical struggle for distributive justice (Fraser, 1995). However, the demand for special treatment (for example for certain ethnic groups, a certain gender, groups with a certain sexual orientation, etc.), which identity politics is often about, obviously conflicts with an idea of universalism, a universalism with its roots in the liberal Enlightenment idea of equal treatment for all (Barry, 2001). ${ }^{19}$ But how should the question of universalism be viewed when it comes to the relationship between parents and children? ${ }^{20}$

The rights of parents hold a strong position, not only as a result of the Universal Declaration of Human Rights, but also traditionally and among many researchers on rights, but how far can and should those rights extend? How, for example, should we weigh parents' rights and their consequences against the value that can be attached to the fact that it is through universal institutions, such as a general education system, that social capital is created?

\section{Social Capital and Deliberative Democracy}

At the end of his book Social traps and the problem of social trust, Rothstein (2005) writes that there is "thus a clear connection between social capital and what has come to be called deliberative democracy" (p. 210). He explains this in terms of the existence of social capital making possible communicative argumentation between parties with differing views. ${ }^{21}$ Does the general education system (as a universal institution) have a specific potential to help lay the foundations of deliberative democracy? Yes, in a general sense we have seen that Rothstein refers to the importance of universal institutions such as schools in producing social capital by avoiding segregation. And he also stresses the need for arenas for social interaction with others, above all with people who are different from ourselves.

Could this be taken to mean that the general education system is not only a potential arena for encounters between people of different kinds, but also that this interaction could be developed into an ordered encounter between different values, different ways of looking at the world, etc.? Could the school system in this way-by gradually shifting its focus from traditional mediation of knowledge to what could be called deliberative communication - contribute to a deliberative democracy, and thus also strengthen social capital, in a manner better suited to our own time? ${ }^{22}$

\footnotetext{
${ }^{19} \mathrm{I}$ can only touch on this issue here, but it is of course a highly complex one. See also the debate in response to Barry's book in Kelly (2002).

${ }^{20}$ This is a rapidly growing field of research, and I will not go into its different strands here. In the next section, however, I will evaluate it in general terms.

21 "The basis of legitimacy in democracy is to be traced back to the presumption that the institutions that claim obligatory power do so because their decisions represent standpoints equally in the interests of all. This presumption can be fulfilled only if such decisions are in principle open to appropriate processes of public deliberation by free and equal citizens" (Benhabib, 2002, pp. 105106, see also Benhabib, 1996).

${ }^{22} \mathrm{Cf}$. Englund (2006). At the same time it has to be said that the gradual dissolution of the general education system as universally based is undermining the basic conditions for this kind of interaction.
} 
What we are faced with here are different kinds of educational activity that can be said to claim to be universal. A school with a strong emphasis on knowledge can be said to represent one standardized kind of universalism, resting on traditional schooling as a knowledge-mediating institution (although the question is whether the term universalism is in fact appropriate in this case). That model can in turn be combined with different types of schools: general schools focusing on the task of imparting knowledge, or independent schools resting on different foundations, ethnic, religious, etc. It is even conceivable - in the light of current tendencies in Sweden - that a standardized school system (general or independent) concentrating on goal achievement is being strengthened by the growth of independent schools with a focus on the knowledge goal, combined with some form of ethnic basis or religious belief. At present we can thus be said to be moving towards a progressively weaker general system of education, supplemented with particularistically-based independent schools that accept standardization and at the same time uphold and reproduce a certain value base. What we/the school system are losing at the same time are the basic conditions for what could be called an interactive universalism, in which schools constitute an arena for encounters between different social, cultural, ethnic, and/or religious groups. $^{23}$

A school that engages in deliberative communication, with its stress on mutual communication between different moral perspectives, thus gives universalism a different, procedurally oriented meaning, and is based on the school serving as an arena for encounters and a weak public sphere (Fraser, 1992). An interactive universalism of this kind attaches importance to developing an ability and willingness to reason on the basis of the views of others and to change perspectives.

Conversations in which different views, conceptions and values are put forward and tested against each other can be used in most school subjects. Educational conversations of this kind may be seen as a complementary and alternative means of knowledge formation, with qualities different from those of the teaching and learning we usually associate with traditional mediation and reproduction of knowledge. In deliberative communication, everyone has to reflect upon his or her views and assumptions by listening, deliberating, seeking arguments, and evaluating in relation to concrete others. Communication of this kind incorporates a collective search for common frames of reference, but also offers scope to analyse what you are not agreed on and why. Deliberative communication can, among other things, offer special possibilities in the multicultural school of today, as a framework for encounters between different cultures. It thus has an important part to play in developing the democratic value base of schooling, which among other things is about the right to have different views.

Here we also can note the possibility of questioning the teacher as an authority, but of course this will be done through argumentation. Good deliberative communication in the classroom may lead to further deliberation between students outside the classroom. Wider occurrence of such meaning-creating conversations between "equals" may perhaps be seen as one of the most important goals of schools - although at the same time it is one that is

\footnotetext{
${ }^{23}$ Interactive universalism "accepts that all moral beings capable of sentience, speech, and action are potential moral conversation partners" (Benhabib, 2002, p. 14).
} 
quite difficult to evaluate, concerned as it is with the development of deliberative attitudes and a deliberative culture. ${ }^{24}$

There is a very strong tradition in schools of mediation and testing of knowledge, with the verbal output of the teacher as the dominant activity, based on rhetorical questions and predetermined answers - in other words, a tradition in which the described focus on deliberative communication is missing. In spite of a growing body of educational and didactics research that demonstrates both the effectiveness of deliberative communication in learning and its importance in the development of deliberative attitudes, and in spite of the fact that many teachers are trying to break with the dominant tradition, this tradition still persists in most classrooms. It is confirmed and supported by the media and educational policy makers, and by the consolidation of traditional schooling by education authorities. This situation is accentuated by a growing pressure to evaluate, based on a narrow concept of knowledge, while knowledge seen in a wider sense, integrated with communication skills, is neglected. ${ }^{25}$

An alternative to evaluating individual skills in Swedish, English, and Mathematics as expressed in test situations could be to analyse the ability of a group of students to formulate and communicate with others their views on different questions. This kind of communicative and cooperative ability I would see as more central and basic from the standpoint of education as a means of developing the communicative rights of all, and, in the long run, the social capital of a society, than the individual skills assessed in the test situations mentioned.

At the level of educational policy, however, attempts to develop deliberative attitudes through deliberative communication seem to be controversial, even if a good deal of interest has been shown by certain educational authorities. ${ }^{26}$ But if such an attempt were a possible project in policy terms, would it be a reasonable project? Is it conceivable that a greater emphasis on deliberative communication in schools would succeed in developing deliberative attitudes, and indeed a social capital that would also establish a stronger basis for deliberative participation in democracy as a whole? Well, it is of course rather difficult to speculate on this issue, but what is perfectly clear is that the school system itself, and the resources it represents in terms of time and teacher professionalism, can make a difference. It does matter how schools are used by the people working in them, and it is reasonable to suggest that schools can potentially make a major contribution towards socialization in terms of attitudes to society, knowledge, and other people.

The professional teacher is faced with a complex choice concerning the design of his or her teaching, the opposite poles of which could be characterized as reproduction of knowledge and individual training of skills, on the one hand, and interactive communication and creation of meaning, on the other. In practice, teaching and learning presumably fall somewhere in between these poles, but the critical question is whether the

\footnotetext{
${ }^{24}$ For a general description of five characteristics of deliberative communication, see Englund (2004, 2006).

${ }^{25}$ It is also clear that the strong (and growing) culture of testing systematically puts some groups at a disadvantage: in some cases, for instance, linguistic (mis)understanding of the tasks set is a massive problem.

${ }^{26}$ Sweden's Ministry of Education (2000) and National Agency for Education (2000) have, for example, tasked educational researchers and others with developing the idea of deliberative communication as one that could be used by teachers.
} 
current emphasis in educational policy on knowledge, facts, and individual training is in danger of resulting in the very opposite: Could knowledge reproduction and training in fact become ineffective when they are technologized and not contextualized in conversation, and communication between teachers and students and between students?

To return here to our original source of inspiration on how social capital develops, namely James Coleman, it may be noted that in his last major work (Coleman, 1990) he attempted to show how the human capital (knowledge and competence) of a professional can only produce good results within a network in which social capital is flowing, that is where there is trust between the participants and the interactive development of competence is mutually supported through continuous communication. This means that the classroom and the relations established within it between teachers and students, and between students, are fundamentally moral in character. Schools as institutions thus have far-reaching socializing consequences, in that what may appear to be technical and instrumental activities (e.g. learning to read and write), like any other classroom activities, can always be ascribed moral meaning. Schools as institutions, and more precisely the relations developed within them, are crucial in the development of a society's social capital. ${ }^{27}$ Ultimately, it is the responsibility of teachers as professionals, based on their moral judgement and assessment, to develop and implement the communicative practices which they believe to be best suited to developing the competencies of their students.

\section{Conclusion}

To conclude, I would like to go back to the question of evaluation of the educational system. In the debate, the more or less hegemonic view is that the efficiency of schools is best measured in terms of knowledge reproduction. ${ }^{28}$ The crucial issue is not the choice of measure itself, that is knowledge reproduction, but what forms of school are most effective in terms of the percentages of their students attaining the goals set and achieving a pass grade. The focus is thus on whether independent schools are more efficient in this respect than general, local authority-run schools, and less interest is shown in whether segregation has been increased by letting "birds of a feather (in social, ethnic and/or religious terms) flock together". Even less attention is paid to the problem of strong middle-class parents and their children withdrawing from the general education system, thereby draining it of resources and competence and undermining its potential to serve as an arena for social and cultural encounters.

A view which sees our schools as an arena for encounters and highlights their potential to create social capital, as an alternative to the comparative assessments of knowledge reproduction and measurements of efficiency in terms of learning of facts that have become so dominant, does not seem to be politically feasible. The role of schools in creating social capital is of course very difficult to measure, but Putnam's analyses and attempts inspired by him to ask questions about the importance of creating social capital by means of universal institutions must be said to be crucial, offering as they do an

\footnotetext{
${ }^{27}$ Selznick (1992) speaks of a kind of institutional integrity as a quality of the professionals working within an institution, when those professionals regard and understand themselves as parts of a larger whole - a society that needs to develop the social capital of its rising generation.

${ }^{28}$ This hegemony can be said to be the result of the neo-liberal and neo-conservative restructuring of the educational systems of the Western democracies over the last two decades.
} 
alternative to the dominance of assessments of knowledge. The latter operate at another level and within different and much shorter time-frames than analyses of social capital, which to a greater degree are concerned with looking at schools in the light of the ongoing transformation of democracy.

The question that can be asked against this background is as follows: How crucial are schools, as an arena for social encounters between different groups (which otherwise would not meet), in the development of social intelligence and trust (social capital), and what, in this context, is the significance of the increasingly marked segregation we are seeing within the education system and the one-sided, often individually focused, emphasis on achievement?

\section{References}

Barry, B. (2001). Culture and equality: An egalitarian critique of multiculturalism. Oxford: Polity Press.

Bauman, Z. (2001). The individualized society. Cambridge: Polity Press.

Benhabib, S. (1992). Situating the self. Gender, community, and postmodernism in contemporary ethics. Oxford: Polity Press.

Benhabib, S. (1996). Toward a deliberative model of deliberative legitimacy. In Seyla (Ed.), Democracy and difference: Contesting the boundaries of the political (pp. 67-94). Princeton, NJ: Princeton University Press.

Benhabib, S. (2002). The claims of culture: Equality and diversity in the global era. Princeton, NJ: Princeton University Press.

Berman, S. (1997). Civil society and political institutionalization. American Behavioral Scientist, $40(5), 562-574$.

Coleman, J. (1988). Social capital in the creation of human capital. American Journal of Sociology, 94, 95-120.

Coleman, J. (1990). Foundations of social theory. Cambridge, MA: Harvard University Press.

Dewey, J. (1916/1985). Democracy and education. In J.A. Boydston (Ed.), John Dewey. The Middle Works 1899-1924 (Vol. 9). Carbondale, IL: Southern Illinois University Press.

Durkheim, E. (1957). Professional ethics and civic morals. London: Routledge.

Englund, T. (1986). Curriculum as a political problem. Changing educational conceptions with special reference to citizenship education. Lund, Sweden: Studentlitteratur/Chartwell Bratt.

Englund, T. (1989a). Offentligt och privat [Public and private; in Swedish]. Forskning om utbildning, 16(1), 46-49.

Englund, T. (1989b). Educational conceptions and citizenship education. In S. Ball \& S. Larsson (Eds.), The struggle for democratic education, equality and participation in Sweden (pp. 32-66). London: Falmer Press.

Englund, T. (1994a). Education as a citizenship right - a concept in transition: Sweden related to other Western democracies and political philosophy. Journal of Curriculum Studies, 26(4), 383-399.

Englund, T. (1994b). Communities, markets and traditional values: Swedish schooling in the 1990s. Curriculum Studies, 2(1), 5-29.

Englund, T. (1996a). Are professional teachers a good thing? In I. Goodson \& A. Hargreaves (Eds.), Teachers' professional lives (pp. 75-87). London: Falmer Press.

Englund, T. (Ed.). (1996b). Utbildningspolitiskt systemskifte? [A system shift in educational policy? In Swedish]. Stockholm: HLS Förlag.

Englund, T. (2000). Deliberativa samtal som värdegrund-historiska perspektiv och aktuella förutsättningar [Deliberative communication as a value foundation-historical perspectives and current preconditions; in Swedish]. Stockholm, Sweden: Skolverket [National Agency for Education]. 


\section{ENGLUND}

Englund, T. (2001, March). Deliberativa samtal —en utgångspunkt för en läroplansarkitektur i det andra moderna? [Deliberative communication-a starting point for a curriculum architecture in the second modernity? In Swedish]. Contribution presented at the NFPF/NERA conference, Stockholm.

Englund, T. (2004). Deliberativa samtal i ljuset av deliberativ demokrati — en fråga om att utveckla deliberativa förhållningssätt [Deliberative communication in the light of deliberative democracy - a question of developing deliberative attitudes; in Swedish]. In R. Premfors \& K. Roth (Eds.), Deliberativ demokrati (pp. 57-76). Lund, Sweden: Studentlitteratur.

Englund, T. (2005). The discourse on equivalence in Swedish educational policy. Journal of Education Policy, 20(1), 39-57.

Englund, T. (2006). Deliberative communication: A pragmatist proposal. Journal of Curriculum Studies, 38(5), 503-520.

Englund, T., \& Quennerstedt, A. (Eds.). (2008a). Vadå likvärdighet. Studier i utbildningspolitisk språkanvändning [What about equivalence? Studies in the use of language in educational policy]. Göteborg: Daidalos.

Englund, T., \& Quennerstedt, A. (2008b). Linking curriculum theory to linguistics: The performative use of equivalence as an educational policy concept. Journal of Curriculum Studies, 40(6), 713-724.

Foley, M., \& Edwards, B. (1998). Beyond Toqueville: Civil society and social capital in comparative perspective. American Behavioral Scientist, 42(1), 5-20.

Fraser, N. (1992). Rethinking the public sphere: A contribution to the critique of actually existing democracy. In C. Calhoun (Ed.), Habermas and the public sphere (pp. 109-142). Cambridge, MA: MIT Press.

Fraser, N. (1995). From redistribution to recognition? Dilemmas of justice in a 'postsocialist' age. New Left Review, 212, 68-93.

Gutmann, A. (1987). Democratic education. Princeton, NJ: Princeton University Press.

Gutmann, A., \& Thompson, D. (1996). Democracy and disagreement. Cambridge, MA: Belknap Press.

Habermas, J. (1987). The theory of communicative action (I-II). Boston, MA: Beacon Press.

Habermas, J. (1996). Between facts and norms: Contributions to a discourse theory of law and democracy. Cambridge: Polity Press.

Hardin, R. (2002). Trust and trustworthiness. New York: Russel Sage Foundation.

Hoel, T. (2001). Skriva och samtala. Lärande genom responsegrupper [Writing and conversing. Learning through response groups; in Swedish]. Lund, Sweden: Studentlitteratur.

Kelly, P. (Ed.). (2002). Multiculturalism reconsidered. Cambridge: Polity Press.

Levi, M. (1998). A state of trust. In V. Braithvaite \& M. Levi (Eds.), Trust and Governance (pp. 77-101). New York: Russell Sage Foundation.

Marshall, T.H. (1949). Class, citizenship and social development. New York: Doubleday.

Ministry of Education. (1994). Läroplan för det obligatoriska skolväsendet [Curriculum for the compulsory comprehensive school system and voluntary schools; in Swedish]. Stockholm, Sweden: Author.

Moreno, L., \& Francia, G. (Eds.). (2004). Educational policies: Implications for equity, equality and equivalence. Örebro, Sweden: Örebro University, Reports from the Department of Education 6.

Nussbaum, M. (1997). Cultivating humanity. A classical defense of reform in liberal education. Cambridge, MA: Harvard University Press.

Olson, M. (2008). Från samhörighet till särart. Förändringar i den svenska skolans medborgarfostrande roll under 1990-talet i relation till valfrihet ochlivärdighot [From community to particularity. Changes to the citizenship education role in Swedish schools in the 1990s in relation to freedom of choice and equivalence; in Swedish]. In T. Englund \& A. Quennerstedt 
(Eds.), Vadå likvärdighet? Studier i utbildningspolitisk språkanvändning (pp. 72-94). Göteborg: Daidalos.

Parsons, T. (1959). The school class as a social system: Some of its functions in American society. Harvard Educational Review, 29(4), 297-318.

Prop. (1950:70). angående riktlinjer för det svenska skolväsendets utveckling [Government bill concerning guidelines for the development of the Swedish education system; in Swedish].

Putnam, R. (1993). Making democracy work: Civic traditions in modern Italy. Princeton, NJ: Princeton University Press.

Putnam, R. (2000). Bowling alone. The collapse and revival of American community. New York: Simon \& Schuster.

Quennerstedt, A. (2006). Kommunen - en part i utbildningspolitiken [The municipality-a participant in educational policy? In Swedish] Örebro, Sweden: Örebro Studies in Education 14.

Rorty, R. (2000). Universality and truth. In R.B. Brandom (Ed.), Rorty and his critics (pp. 1-30). Oxford: Blackwell.

Rothstein, B. (1988). Noteringar om privat och offentligt inom skolvärlden [Notes on private and public in the world of schooling; in Swedish]. Forskning om utbildning, 15(3), 29-34.

Rothstein, B. (1998). Just institutions matter: the moral and political logic of the universal welfare state. Cambridge: Cambridge University Press.

Rothstein, B. (2005). Social traps and the problem of trust. Cambridge: Cambridge University Press.

Skolverket [The National Agency for Education]. En fördjupad studie om värdegrunden —om möten, relationer och samtal som förutsättningar för arbetet med de grundläggande värdena [An in-depth study of the value foundation of schools - encounters, relationships and conversations as necessary conditions for the development of basic values; in Swedish]. Skolverket, Dnr 2000: 1613.

SOU. [Government Official Reports]. (1948). 1946 års skolkommissions betänkande med förslag till riktlinjer för det svenska skolväsendets utveckling [Report of the 1946 School Commission, with proposals for guidelines on the development of the Swedish education system; in Swedish].

SOU. [Government Official Reports]. (1990). Demokrati och makt i Sverige [Democracy and power in Sweden; in Swedish].

Stolle, D. (2003). The sources of social capital. In M. Hooghe \& D. Stolle (Eds.), Generating social capital (pp. 19-42). New York: Palgrave MacMillan.

Tarrow, S. (1996). Making social science work across space and time. A critical reflection on Robert Putnam's Making Democracy Work. American Political Science Review, 90(2), 389-397.

Utbildningsdepartementet [The Ministry of Education]. (2000). Värdegrundsboken om samtal för demokrati i skolan [A book about basic values: Conversation as a tool for democracy in schools; in Swedish]. Stockholm, Sweden: Utbildningsdepartementet.

Wahlström, N. (2002). Om det förändrade ansvaret för skolan. Vägen till mål- och resultatstyrning och några av dess konsekvenser [On the shift of responsibility for compulsory schooling. The path to management by objectives and results and some of its consequences; in Swedish]. Örebro: Örebro Studies in Education 3.

Wahlström, N. (2008). Likvärdighet och kunskap - en diskussion utifrån två mångtydiga begrepp [Equivalence and knowledge - a discussion in the light of two multifaceted concepts]. In T. Englund \& A. Quennerstedt (Eds.), Vadå likvärdighet? Studier $i$ utbildningspolitisk språkanvändning (pp. 120-146). Göteborg: Daidalos.

Yamagishi, T. (2001). Trust as a form of social intelligence. In K. Cook (Ed.), Trust in society (pp. 121-147). New York: Russel Sage Foundation. 